\title{
Digital Learning Environment in Higher Education: New Global Issues
}

\author{
Elena Malkawi ${ }^{1, *}$, and Marina Khayrullina ${ }^{2}$ \\ ${ }^{1}$ CTL Eurocollege, Faculty of Business, 118 Spyrou Kyprianou Ave., 3077 Limassol, Cyprus \\ ${ }^{2}$ Novosibirsk State Technical University, Faculty of Business, 20 Karl Marks Pr., 630073 \\ Novosibirsk, Russia
}

\begin{abstract}
.
Research background: Living in a digitalized connected world changes the dynamic of the learning process. Recent issues in the world economy and society have increased the demand for online education drastically. But many enterprises in higher education find themselves unprepared to satisfy this demand effectively because digital learning is a relatively new and under-researched field especially regarding digital instruments and social aspects. For this study we adopted connectivism learning theory proposed by George Siemens in 2005 together with the "old" behaviourism, cognitivism, and constructivism theory put forward by Ertmer and Newby in 1993.

Purpose of the article: The study intended to investigate elements of digital learning process using student feedback and to suggest ways to improve the quality of digital higher education based on learning theories applied to digital environment.

Methods: A total of 2347 university students participated in this study. Data were collected through an online survey and were analysed with the use of SPSS software.

Findings \& Value added: The study revealed that students pinpoint three groups of problems in online learning: the process of getting feedback form tutor and peers; the process of concentration and self-management; the technical difficulties of staying connected. The paper studies the theoretical background of problematic areas and proposes tools for their improvement.
\end{abstract}

Keywords: digital learning environment; connectivity; online education; quality of higher education.

JEL Classification: $I 21 ; I 23 ; O 35$.

\footnotetext{
*Corresponding author: elenamalk@ctleuro.ac.cy
} 


\section{Introduction}

The digital economic environment is the economic activity that is the result of billions of everyday online interactions between people, businesses, devices, data, and processes. This hyperconnectivity is the result of the Internet, mobile technology and the internet of things (IoT). For this reason, the digital economy is also sometimes called the Internet Economy, Web Economy, or New Economy. Digitalization is also bringing about broad sociological changes by influencing all aspects of society, including the way people interact and, consequently, the dynamic of the learning process.

To explain the concept of the digital environment of the economy and society, present research is using a concept of composite Digital Economy and Society Index (DESI) that has been published every year since 2014 by the European Commission [1]. According to DESI, the digital environment of the economy and society is evaluated across six levels: connectivity, human capital digital skills, use of Internet services by citizens, integration of digital technology by businesses, digital public services, research and development ICT. In order to investigate the learning process within the digital society, present research has mostly focused on connectivity and human capital digital skills, as they are the most relevant to the question.

Connectivity in regard to a learning process means that a learner is connected to the source of information (for example, databases), to the source of experience (for example, teacher), to the coordinator of learning process (educational institution), and to a group or to a community of other learners. In response to hyperconnectivity, human skills are reshaping and, consequently, effective learning design requires a very different approach. Due to global issues in January-May 2020 the majority of institutions in higher education made a drastic move towards online education but were faced with a number of issues regarding the learning design of online programmes.

This research explores the experiences of 2347 students who took online courses in spring 2020 in Novosibirsk State Technical University (NSTU) which offers about 100 programs of study in technical, economic and humanitarian fields from Bachelor's to post-doctoral levels. The researchers attempted to shed light on the student's online learning experiences, when online learning was difficult to them or perceived as not effective.

\section{Research methodology}

The research consisted of two phases. Phase One included questionnaire surveys to explore students' attitude towards technology and any negative experiences that students had in the online learning process of spring 2020. Phase Two aimed to examine the theoretical background and best practices in problematic areas (explored throughout phase One) in order to formulate recommendations to improve the quality of higher education in digital society.

Phase One tool included an online questionnaire survey which was answered by 2347 university students. The survey gauged the participants' demographic information, as well as participants' opinions regarding learning problems related to the design of online courses in spring 2020 (questionnaire' section Q1.1 with 15 items of multiple choice answers and section Q1.2 with one open-end answer); opinions regarding learning efficiency and course design (section Q2, 11 items of multiple choice answers and attitude towards technology (section Q3 with five-point Likert scale, 15 items). Average time taken to answer the questions was about 20 minutes. Phase Two consists of a review of existing learning theories and their practical applications in digital learning environment.

The researchers performed quantitative and qualitative analyses. Statistical analysis was done with the use of SPSS. First, the normality of the data from each section of the questionnaire was tested by calculating the values of Skewness and Kurtosis. It is commonly accepted that data are normally distributed when Skewness and Kurtosis are respectively 
within the range of \pm 1 and \pm 3 [2]. The results revealed that the distribution of the all the data was close to normal distribution.

The statistics employed for the analysis of the scale of reliability of questionnaire in sections Q1 and Q2 was Cronbach's Alpha. The initial reliabilities of the variables were 0.803 and 0.801 respectively, which indicate good internal consistency. Additionally, content validity was assessed by carefully checking the measurement methods against the concept of effective course design. To ensure the validity and reliability of the construct of the Q3 tool, researchers performed factor analysis on the responses to the questions about attitudes toward technology. Only the items with strong factor loadings higher than 0.5 were used for analysis purpose.

Qualitative descriptive analysis used to understand and summarize specific experiences of students [3], p.326. The themes of participants' answers to the open-ended question were generated and described by coding the text data, developing a description, and defining main themes from the data. The coding was mainly completed by the first author, and second author checked and reviewed the codes and themes to insure that the coding processes were consistent and data matched the codes and themes that had been set.

The purpose of the survey was to investigate university students' recent experience in online learning. It was administered to all 11517 students of NSTU as a convenient sample and $20 \%$ of them are participated. Among the participants $40 \%$ were females, and $60 \%$ were males. The majority of them (97\%) were between 17 and 25 years old (weighted mean 20 years old). Forty two percent of participants were students studying toward a master's degree and $20 \%$ toward a bachelor's degree.

\section{Data analysis and results}

The technology acceptance model (TAM) is one of the theories primarily used by existing studies on students' attitudes towards online courses [4]. This model examines students' willingness to use technology based on their perceptions of ease of use and usefulness [5]. Students who are less willing to accept technology are more likely to report having negative experience when taking part in online learning. His/her negative experience is the result of internal, subjective norm towards technology, and not external factors such as online course design, which is a point of interest in this study. This research applied a survey to find out students' attitudes toward technology. The results of the survey (see Appendix 1) with 3.38 points out of 5.00 (Likert scale) revealed that participants on the whole appreciate and accept technology. Consequently, their personal intentions towards technology may not have a negative influence on their perceptions of online course design.

Moreover, only about 30 percent of participants had previous experience of onlineeducation on platforms like Coursera, edX, Stepik, and currently $46 \%$ of participants stated that they prefer to substitute some of their offline courses with online courses. This illustrates a positive dynamic in students' opinions regarding online learning experience in spring 2020. Analysed students' opinions about learning design, tabulated in Table 1 support above statement, as $49 \%$ of participants noted that "the mode of study (online/physical presence) is not important as long as it serves the purpose of study" and only $12 \%$ of participant stated that "the best way to study in university is by physical presence".

Table 1. Students' opinions regarding learning design in university

\begin{tabular}{|l|l|}
\hline & $\mathbf{\%}$ \\
\hline $\begin{array}{l}\text { Mode of study (online/ physical presence) is not important as long as it serves the } \\
\text { purpose of study }\end{array}$ & 49.0 \\
\hline $\begin{array}{l}\text { It is very important to have open communicational channel with the tutor and } \\
\text { peers for effective learning }\end{array}$ & 25.7 \\
\hline The best way to study in university is by physical presence & 12.2 \\
\hline
\end{tabular}




\begin{tabular}{|l|l|}
\hline It is very important to work toward a new discoveries while studying the course & 8.6 \\
\hline I don't know & 4.5 \\
\hline TOTAL & 100 \\
\hline
\end{tabular}

In general, $56 \%$ of participants reported that they didn't have any learning problems by taking courses online. Although 1039 students (44\%) acknowledged different types of learning problems caused by the design of online courses. Difficulty points are allocated in descending order in Table 2 according to frequencies they are mentioned by students. The most frequent difficulty mentioned by students is number 1 "Manage my self-study process" and the least frequent is number 14 "Have a suitable devise or internet connection to study online".

Table 2. Difficulty points in online learning process

\begin{tabular}{|l|l|c|c|}
\hline & \multicolumn{1}{|c|}{ I found difficult to: } & $\begin{array}{c}\text { Number of } \\
\text { answers }\end{array}$ & Frequency, \% \\
\hline 1 & Manage my self-study process & 1039 & 100.00 \\
\hline 2 & Study at home & 987 & 95.00 \\
\hline 3 & Get feedback from tutor & 979 & 94.23 \\
\hline 4 & Have a discussion with the tutor & 907 & 87.30 \\
\hline 5 & $\begin{array}{l}\text { Provide and justify my points of view to } \\
\text { instructors }\end{array}$ & 819 & 78.83 \\
\hline 6 & Manage technical issues & 774 & 74.49 \\
\hline 7 & Communicate with peers & 711 & 68.43 \\
\hline 8 & Remain focused during video lessons & 538 & 51.78 \\
\hline 9 & $\begin{array}{l}\text { Feel connected to society while staying mostly } \\
\text { online }\end{array}$ & 491 & 47.26 \\
\hline 10 & Have a group discussion regarding a subject & 469 & 45.14 \\
\hline 11 & Find a suitable place to study at home & 360 & 28.10 \\
\hline 12 & Use a web camera at home & 292 & 21.66 \\
\hline 13 & $\begin{array}{l}\text { Get familiar with UI of online learning } \\
\text { applications }\end{array}$ & 225 & 11.93 \\
\hline 14 & $\begin{array}{l}\text { Have a suitable devise or internet connection to } \\
\text { study online }\end{array}$ & 124 & 9.05 \\
\hline 15 & Other & 94 & 100 \\
\hline & $\begin{array}{l}\text { Total number of students who answered this } \\
\text { part of survey }\end{array}$ & 1039 & \\
\hline
\end{tabular}

The statements tabulated above where proposed to participants as multiple choice answers. In the open-end section of the survey the participants were asked to describe in detail the problems they had been faced with. Two hundred and eighty six students answered the questionnaire in open-end answer form. An analysis of the main themes of their answers can be found in Table 3 below, where items are grouped according to identified points of difficulty together with the items from the multiple choice section. The quantitative results of the survey and the qualitative analysis of the quotes revealed the following list of negative experiences that students had in the online learning process: (1) insufficient level of selfregulating and technical skills of the student; (2) unestablished processes of communication with tutors and peers; (3) self-isolation at home where is difficult to create a learning environment; (4) tutors' online teaching skills are at insufficient level. 
Table 3. Negative experiences that students had in the online learning process.

\begin{tabular}{|c|c|c|c|c|}
\hline \multicolumn{2}{|c|}{ Multiple choice answers } & \multicolumn{3}{|c|}{ Open-end answers } \\
\hline $\begin{array}{l}\text { Statement of } \\
\text { questionnaire } \\
\text { "I found difficult } \\
\text { to:" }\end{array}$ & $\begin{array}{l}\text { Friquency, } \\
\text { Number }\end{array}$ & $\begin{array}{l}\text { Themes } \\
\text { identified }\end{array}$ & Example quote & $\begin{array}{l}\text { Friquen } \\
\text { cy, } \\
\text { Number } \\
(\%)\end{array}$ \\
\hline \multicolumn{5}{|c|}{ 1. Self-regulating and technical skills of students } \\
\hline $\begin{array}{l}\text { Manage my self- } \\
\text { study process }\end{array}$ & 1039 & $\begin{array}{l}\text { Massive load of } \\
\text { materials for } \\
\text { self-study that } \\
\text { are difficult to } \\
\text { manage }\end{array}$ & $\begin{array}{l}\text { "the load of the materials } \\
\text { for self-study increased } \\
\text { and I don't know how to } \\
\text { manage my time } \\
\text { efficiently" }\end{array}$ & $\begin{array}{l}58 \\
(20 \%)\end{array}$ \\
\hline $\begin{array}{l}\text { Manage technical } \\
\text { issues }\end{array}$ & 774 & $\begin{array}{l}\text { Technical } \\
\text { problems related } \\
\text { to online } \\
\text { learning } \\
\text { processes }\end{array}$ & & $\begin{array}{l}34 \\
(12 \%)\end{array}$ \\
\hline $\begin{array}{l}\text { Remain focused } \\
\text { during video lessons }\end{array}$ & 538 & $\begin{array}{l}\text { Self- } \\
\text { management of } \\
\text { personal } \\
\text { productivity } \\
\text { when studying } \\
\text { online }\end{array}$ & $\begin{array}{l}\text { "impossible to concentrate } \\
\text { on learning materials } \\
\text { when surrounded by } \\
\text { family" }\end{array}$ & $\begin{array}{l}30 \\
(11 \%)\end{array}$ \\
\hline $\begin{array}{l}\text { Get familiar with UI } \\
\text { of online learning } \\
\text { applications }\end{array}$ & 225 & & & \\
\hline Total group 1 & 2576 & & & $\begin{array}{l}122 \\
(43 \%)\end{array}$ \\
\hline \multicolumn{5}{|c|}{ 2. Communication and interactions } \\
\hline $\begin{array}{l}\text { Get feedback from } \\
\text { tutor }\end{array}$ & 979 & \multirow{6}{*}{$\begin{array}{l}\text { Difficulties in } \\
\text { contacting an } \\
\text { instructor for } \\
\text { feedback and to } \\
\text { discuss matter } \\
\text { with peers }\end{array}$} & \multirow{6}{*}{$\begin{array}{l}\text { "feedback from the } \\
\text { teacher takes too long and } \\
\text { this makes the learning } \\
\text { process very slow and } \\
\text { boring"; } \\
\text { "most of the teachers are } \\
\text { not available for contact in } \\
\text { case there are unplanned } \\
\text { questions that students are } \\
\text { facing in the self-study } \\
\text { process" }\end{array}$} & \multirow[t]{6}{*}{$\begin{array}{l}95 \\
(33 \%)\end{array}$} \\
\hline $\begin{array}{l}\text { Have a discussion } \\
\text { with the tutor }\end{array}$ & 907 & & & \\
\hline $\begin{array}{l}\text { Provide and justify } \\
\text { my points of view to } \\
\text { instructors }\end{array}$ & 819 & & & \\
\hline $\begin{array}{l}\text { Communicate with } \\
\text { peers }\end{array}$ & 711 & & & \\
\hline $\begin{array}{l}\text { Feel connected to } \\
\text { society while staying } \\
\text { mostly online }\end{array}$ & 491 & & & \\
\hline $\begin{array}{l}\text { Have a group } \\
\text { discussion regarding } \\
\text { a subject }\end{array}$ & 469 & & & \\
\hline Total group 2 & 4376 & & & $\begin{array}{l}95 \\
(33 \%) \\
\end{array}$ \\
\hline \multicolumn{5}{|l|}{ 3. Location } \\
\hline Study at home & 987 & Self-isolation & \multirow{4}{*}{$\begin{array}{l}\text { "it's difficult to focus on } \\
\text { the studying process in the } \\
\text { comfort of my home" }\end{array}$} & \multirow{4}{*}{$\begin{array}{l}35 \\
(12 \%)\end{array}$} \\
\hline $\begin{array}{l}\text { Find a suitable place } \\
\text { to study at home }\end{array}$ & 360 & & & \\
\hline $\begin{array}{l}\text { Use a web camera at } \\
\text { home }\end{array}$ & 292 & & & \\
\hline $\begin{array}{l}\text { Have a suitable } \\
\text { devise or internet } \\
\text { connection to study } \\
\text { online }\end{array}$ & 124 & & & \\
\hline
\end{tabular}




\begin{tabular}{|l|l|l|l|l|}
\hline Total group 3 & $\mathbf{1 7 6 3}$ & & & $\begin{array}{l}\mathbf{3 5} \\
\mathbf{( 1 2 \% )}\end{array}$ \\
\hline 4. Skills of the tutor & & $\begin{array}{l}\text { Course design } \\
\text { and } \\
\text { requirements }\end{array}$ & $\begin{array}{l}\text { "inconsistency of course } \\
\text { design and instructors' } \\
\text { requirements across } \\
\text { different subjects" }\end{array}$ & $\begin{array}{l}77 \\
(27 \%)\end{array}$ \\
\hline & & Tutor' skills & $\begin{array}{l}\text { "instructors need training } \\
\text { in online teaching" }\end{array}$ & $17(6 \%)$ \\
\hline Total group 4 & $\mathbf{0}$ & & & $\begin{array}{l}\mathbf{9 4} \\
\mathbf{( 3 3 \% )}\end{array}$ \\
\hline $\begin{array}{l}\text { Total number of } \\
\text { students who } \\
\text { answered this part of } \\
\text { survey }\end{array}$ & 1039 & & $\begin{array}{l}286 \\
(100 \%)\end{array}$ \\
\hline
\end{tabular}

Regarding the problems related to self-isolation at home (group 3) there is not much that could be done by universities. However, the remaining groups of problems could be managed in two ways. One of them is to develop the digital skills of students and academic staff. And another is to establish an appropriate level of connectivity. The importance of the connectivity was also emphasized by students when they expressed their opinions regarding effective course design. The tabulated results of the mentioned part of survey can be found in Table 4.

Table 4. Students' opinions regarding course design.

\begin{tabular}{|l|l|}
\hline & $\mathbf{\%}$ \\
\hline $\begin{array}{l}\text { Course design developed by course instructor with the aim of facilitating } \\
\text { and coordinating group communication among students }\end{array}$ & 29.5 \\
\hline $\begin{array}{l}\text { Course design developed by course instructor taking into account the best } \\
\text { interests and needs of students }\end{array}$ & 19.2 \\
\hline $\begin{array}{l}\text { Course design developed in cooperation between course instructor and } \\
\text { students }\end{array}$ & 18.7 \\
\hline $\begin{array}{l}\text { Course design developed by course instructor based on his professional } \\
\text { opinion }\end{array}$ & 13.0 \\
\hline Course design tailored to the individual needs of every student & 9.9 \\
\hline I don't know & 9.7 \\
\hline TOTAL & 100 \\
\hline
\end{tabular}

\section{Applicable theories - discussion}

There are three comprehensive learning theories that are often employed to create a learning environment: Behaviorism, Cognitivism, and Constructivism. Behaviorism states that reality is external and is objective, and knowledge is gained through experiences. Cognitivism states that reality is interpreted, and knowledge is negotiated through experience and thinking. Constructivism states that reality is internal, and knowledge is constructed [6].

Since learning is a complicated and time-consuming process and strongly influenced by the individual's experience and knowledge, appropriate learning strategies change according to the learner's proficiency and learning goals. This means that when selecting a learning strategy, it is necessary to give careful consideration both the learner's knowledge and cognitive processing levels, which are required to handle the target learning task. For example, it is better to use Behaviorism strategies when learners are trying to accumulate basic knowledge about a subject, because learners' knowledge is too low to use cognitive strategies. And at the stage of knowledge implementation, when it is necessary to 
demonstrate that the acquired knowledge can be used effectively in practice, a Cognitivism learning strategy is appropriate [6], p.69. Behaviorism, Cognitivism, and Constructivism theories are as useful today as in the past and are still used extensively by various instructional designs in education.

These theories, however, were developed before a shift to digitalized economy and digitalized society. Living in a digitalized connected world changes how we live, how we communicate, and how we learn. For example, a major part of cognitive information processing can now be delegated to technology; reliability and expiration of information today is more important than ever before. Know-how and know-what is being supplemented with know-where (the understanding of where to find knowledge needed) [7], p2. George Siemens put forward Connectivism learning theory which states that the process of getting information we "need for tomorrow is more important than what we know today" and to provide a learning theory that is more relevant to the next generation of learners due to their increasingly connected nature. Principles of Connectivism are formulated by the author as follows: [7]

- Learning and knowledge rests in diversity of opinions.

- Learning is a process of connecting specialized nodes or information sources.

- Learning may reside in non-human appliances.

- Capacity to know more is more critical than what is currently known

- Nurturing and maintaining connections is needed to facilitate continual learning.

- Ability to see connections between fields, ideas, and concepts is a core skill.

- Currency (accurate, up-to-date knowledge) is the intent of all connectivist learning activities.

- Decision-making is itself a learning process. Choosing what to learn and the meaning of incoming information is seen through the lens of a shifting reality. While there is a right answer now, it may be wrong tomorrow due to alterations in the information climate affecting the decision.

Principles of Connectivism are partially applied in a community of inquiry (CoI) and a community of practice $(\mathrm{CoP})$. They are both excellent examples of the applied principle "Learning and knowledge rests in diversity of opinions".

The Community of Inquiry (CoI) framework has been one of the most used and researched educational frameworks. The research ranges from subjects like "How useful is the model in today's learning environment", "Can it be improved?" or "Can new presences be added to the framework". As Garrison [8] suggests it's time to turn to the practical aspects of a CoI, as conciderable attention has been directed at issues of facilitation. More studies can be done on how educators can use the CoI model to integrate the best technologies into curricula in order to empower them and help students learn, [9].

The concept of CoP is fundamentally based on learning theories that describe learning through active participation in the shared practices of social communities. For example, in an article published in 2018, Kyungmee Lee briefly discusses the concept of CoP and proposes an alternative way of conceptualizing online learning and its boundaries, based on a double-layered Community of Practice model as a means of facilitating authentically constructivist online learning. The model conceptualizes online learning as interlinked processes of participation and socialization in multiple communities across online- and offline-" "layers" of learners' lives [10].

In both CoI and CoP cases the community is composed of a group of individuals united by a common goal, such as learning about a specific subject area. Both of these communities allow their members to contribute information, which is then used by others to further their knowledge or experience. Indeed, it is possible for two or more communities to examine different perspectives of the same topic or different topics in the same subject area, and then 
merge and exchange information and experience which is equally applicable to the other community [11].

Instructional designer and course facilitators who use the community approach are doing several things. First, they are creating a cohort of students who are engaging collaboratively to learn about the material. Secondly, they are creating an environment where there is an emphasis on cognition and critical thinking, providing the students with the ability to not only exchange knowledge, but to expand upon it through discussion. Finally, when the students become emotionally involved in the information, it fuels an intrinsic motivation to learn and discover more, which in turn benefits the community.

Principles of Connectivism "Learning is a process of connecting specialized nodes or information sources" and "Learning may reside in non-human appliances" assume that learners have open access to the sources of information and can practice their data literacy skills, discussed later in this chapter. In this context, open data and open educational resources (including games) have great potential values.

Open data is "digital data that is made available with the technical and legal characteristics necessary for it to be freely used, reused, and redistributed by anyone, anytime, anywhere" [12]. This concept made diverse data sets from various organizations publicly available, including government spending, research outcomes, archives, surveys, environmental sensing, and museum collections. While sharing data online is not new, the formalization of open data has created a global movement and led to a huge growth in the breadth and depth of data available [13]. However, approaches to connecting open data to learning design are not in mainstream use. Detailed thematic analysis was conducted by Tim Coughlan to identify patterns and relationships in open data-based practices that have already emerged [13]. Results and framework presented in his research offer a conceptual starting point to adapt open data to learning design.

Open educational resources (OER) are "teaching, learning, and research resources that reside in the public domain or have been released under an intellectual property license that permits their free use and repurposing by others. OER include full courses, course materials, modules, textbooks, streaming videos, tests, software, and any other tools, materials, or techniques used to support access to knowledge." [14]. The fact that learning materials have open access makes them a valuable element of the digital learning environment, where every learner is encouraged to connect specialized nodes of information sources and exercise ability to see connections between fields, ideas, and concepts.

When speaking about digital human skills, we need to consider three principles from Connectivism theory. These are: "capacity to know more is more critical than what is currently known", "ability to see connections between fields, ideas, and concepts" and "decision-making is itself a learning process". According to DESI, there are two levels of digital human skills, which are: basic level (like internet user skills); and advanced level (ICT graduates and ICT specialists). Advanced level skills (or data literacy) broadly combines technical and statistical skills with the ability to draw meaning by posing questions, interpreting data and analyses effectively, and also in developing skills in reading and creating visualizations [15]. Notably, that digital concept of education requires constant development of data literacy skills from students as well as from teaching staff.

\section{Conclusion}

The study revealed that students identified three categories of negative experiences during their online learning process: insufficient level of self-regulating and technical skills of the student; unestablished processes of communication with tutors and peers; tutors' online teaching skills are at an insufficient level. To avoid problems in future, learning design 
must consider how to develop the digital skills of students and academic staff and how to establish an appropriate level of connectivity.

Theoretical studies and best practices in the areas related to students' negative experiences suggest that a digital learning environment should be carefully constructed to implement a community of inquiry and/or practice where students can collectively assemble information, discuss it and determine its importance and relevance. Designers need to implement models that will facilitate all of the desired skills, including digital literacy, with the use of authentic activities, ideas that can be researched by students, open data and open educational resources. Well-established conceptual frameworks and pedagogical strategies of higher education can and should be extended to meet the new challenges posed by digital environment.

Table 5. Appendix 1

\begin{tabular}{|l|l|l|}
\hline & \multicolumn{1}{|l|}{} & From 1 to 5 \\
\hline 1 & Technology helps me to control my daily routine & 3.83 \\
\hline 2 & Technology improves the quality of my life & 4.05 \\
\hline 3 & Technology provides my mobility & 3.71 \\
\hline 4 & Technology improves my productivity & 3.64 \\
\hline 5 & I am able to learn new technology independently/without external support & 3.26 \\
\hline 6 & Among my friends I am a first person to use new technology & 2.66 \\
\hline 7 & $\begin{array}{l}\text { I am constantly monitoring technological developments in areas of my } \\
\text { interests }\end{array}$ & 3.18 \\
\hline 8 & $\begin{array}{l}\text { When I receive technical support I feel unsecured, because they know } \\
\text { more than I do }\end{array}$ & 3.04 \\
\hline 9 & I hardly can understand comments of technical support staff & 3.71 \\
\hline 10 & Seems to me, new technology can't be used by ordinary person & 3.71 \\
\hline 11 & I never find it easy to understand user' manual for technological products & 3.58 \\
\hline 12 & People unnecessarily depend on technology that replacing human skills & 2.67 \\
\hline 13 & $\begin{array}{l}\text { Variable technological tools distracting people and it is harmful for } \\
\text { society }\end{array}$ & 3.19 \\
\hline 14 & Technology is badly affecting the way people communicate and interact \\
\hline 15 & $\begin{array}{l}\text { When I communicate with organization that available online only, I feel } \\
\text { unsecured }\end{array}$ & 3.19 \\
\hline & MEAN & $\mathbf{3 . 3 8}$ \\
\hline
\end{tabular}

\section{References}

1. European Commission Policy (2020). The Digital Economy and Society Index (DESI). European Commission. Retrieved from: https://ec.europa.eu/digital-singlemarket/en/desi

2. Tabachnick, B.G., Fidell, L.S. (2013). Using multivariate statistics. Boston: Pearson Education.

3. Silverman, D. (2017). Doing qualitative research. California: SAGE Publications.

4. Zhu, Y., Zhang, J.H., Au, W., Yates, G. (2020) University students' online learning attitudes and continuous intention to undertake online courses: a self- regulated learning perspective. Educational Technology Research and Development, 68(3), 1485-1519

5. Davis, F. D. (1989). Perceived usefulness, perceived ease of use, and user acceptance of information technology. MIS Quarterly, 13(3), 319-340

6. Ertner, P.A., Newby, T.J. (1993). Behaviorism, Cognitivism, Constructivism: Comparing Critical Features from an Instructional Design Perspective. Performance Improvement Quarterly, 26(2), 43-46. 
7. Siemens, G. (2005). Connectivism: A learning theory for the digital age. International Journal of Instructional Technology and Distance Learning, 2(1).

8. Garrison, D.R. (2011). E-Learning in the 21stcentury: A framework for research and practice. London: Routledge/Taylor and Francis.

9. Garrison, D. R. (January 2, 2018). Designing a Community of Inquiry. Community of Inquiry. Retrieved from: http://www.thecommunityofinquiry.org/editorial9

10. Kyungmee, L. (2018). Everyone already has their community beyond the screen: reconceptualizing online learning and expanding boundaries. Educational Technology Research and Development, 66(5), 1255-1268

11. Hare C. (2019, Aug 27). Beyond Behaviorism, Cognitivism and Constructivism: Learning for the 21st Century. Age of Awareness. Retrieved from: https://medium.com/age-of-awareness/beyond-behaviorism-cognitivism-andconstructivism-learning-for-183a5525defd

12. Open Data Charter. (2020, Sep). Principles. Open Data Charter. Retrieved from: https://opendatacharter.net/principles/

13. Coughlan, T., (2020). The use of open data as a material for learning. Educational Technology Research and Development, 68(1), 383-411

14. Hewlett Foundation (2020, Sep) Open Education Defined. William and Flora Hewlett Foundation. Retrieved from: https://hewlett.org/strategy/open-education/

15. Crusoe, D. (2016). Data Literacy defined pro populo: To read this article, please provide a little information. The Journal of Community Informatics 12(3), 27-46 